\title{
714 自動車用シート構造の構造・音響連成特性の実験解析 \\ Experimental Analysis of Vibro-acoustic Characteristics of Automotive Seat Structures Having Porous Materials
}
福島 亨(群大院) 正 山口 誉夫(群馬大) 正 山本 崇史(日産自) 正 丸川 新一(日産自) 藤本 雅士(群大院) 城田 育夫(群大院) 堀 裕一(群馬大)

\begin{abstract}
Toru FUKUSHIMA, Graduate school of Gunma University, Tenjincho 1-5-1, Kiryu, Gunma Takao YAMAGUCHI, Gunma University, Tenjincho 1-5-1, Kiryu, Gunma Takashi YAMAMOTO, NISSAN Moters, Okatsukoku 560-2, Atsugi, Kanagawa Shinichi MARUYAMA, NISSAN Moters, Okatsukoku 560-2, Atsugi, Kanagawa Masashi FUJIMOTO, Graduate school of Gunma University, Tenjincho 1-5-1, Kiryu, Gunma Ikuo SHIROTA, Graduate school of Gunma University, Tenjincho 1-5-1, Kiryu, Gunma Yuichi HORI, Gunma University, Tenjincho 1-5-1, Kiryu, Gunma
\end{abstract}

\begin{abstract}
Automotive seat structures mainly include metal frames, porous materials and surface materials. There are two media (i.e. internal air and resin block) in the porous materials. By carrying out our model test, the porous materials had sound absorption for cavity resonance. And they also had damping effects for the structural resonance of the metal frame. Under an acoustic excitation, vibration amplitudes of the metal frame increased by attaching the porous materials. It's " an effect of a sail" of the resin block in the porous material, which increases vibration level of the seat metal frame by receiving sound pressure. We also observed the similar phenomena when a thin leather sheet is covered on the foam with the metal frame.
\end{abstract}

Key Words: Noise, Vibration, Seat / Damping, Sound Absorption, Vibro-acoustic

\section{A1. ま え がき}

自動車用内装構造の中で，シートは大きな表面積を占めて おり，従来から車内の音響特性に影響があることが知られて いる．本報告では，図A 1 (a)のような前席シート構造の簡易 モデルと (b) のような後席シート構造の簡易モデルについて, フレームやパネルのみの場合とそれにフォームと取り付けた 場合，さらに本皮をフォームに取り付けた場合の条件でハン マリング加振実験と音響加振実験を行い, シート構造の振動 音響連成特性を調べた.

\section{A2. 実 験 方 法}

ハンマリング加振実験は，それぞれ図 A 1 に示してある加 振点に圧電体力変換子を内蔵したインパクトハンマーで加振 し, 観測点に加速度ピックアップを設置し加速度を計測した. これによりフレームの構造振動に及ぼすフォームの影響を調 ベた，音響加振実験の実験装置の概要は, 図 A2 のようになっ ている(前席の例)．右側の大きなボックスは車内空間を模擬 した閉空間となっており，その中央付近にシート構造の簡易 モデルが設置してある. 左のスピーカーボックスからパイプ を通してホワイトノイズで音響加振を行った.

\section{A3. 結 論}

ハンマリング実験から，シートフォームは金属フレームや パネルの振動への制振効果を持つことが確認できた．音響加 振実験から，フォームが存在すると閉空間の共鳴は吸音され ることが確認できた．前席シート構造ではフォームが存在す ると「帆の働き」により金属フレームの振動がなんと増加し た，前席シート構造では，本革をフォームの全表面に接着し た条件でも同様な現象が現れた. 金属パネルを用いた後席シ 一ト構造では，このような現象は現れなかった.

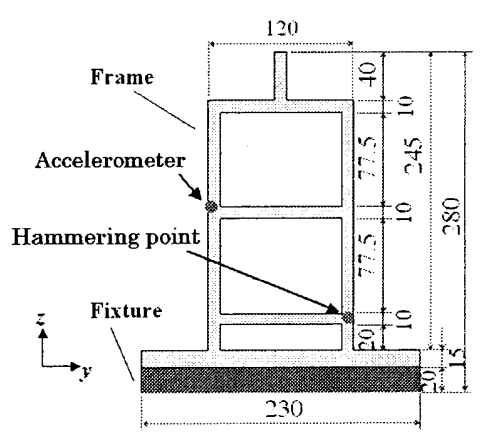

(a) Front seat structure

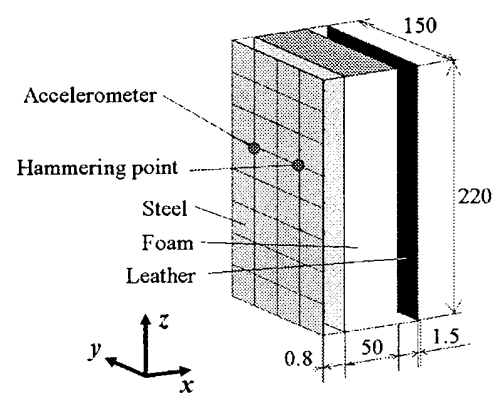

(b) Rear seat structure

Fig.A1 Specimen for a front and rear seat structure

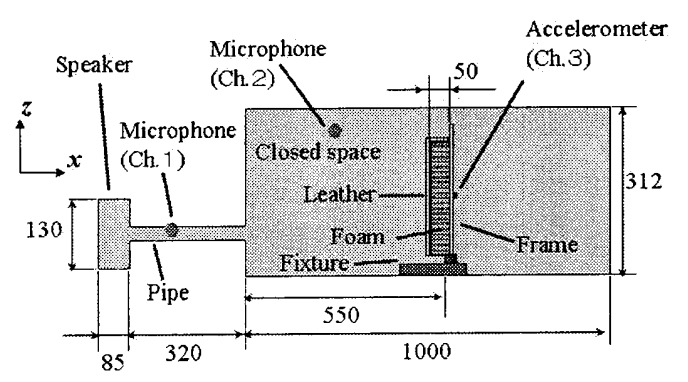

Fig.A2 Experiment setup of acoustic excitation test for a front seat structure 


\section{1. まえがき}

自動車用内装構造の中で，シートは大きな表面積を占めて おり，従来から車内の音響特性に影響があることが知られて いる．車内音の低周波数域に执てては，シートによる車室の 共鳴周波数の変化と, 音響インピーダンスの変化が報告され ている ${ }^{(2),(3),(4)}$ ，車内音の高周波数域ではシートが多孔質吸音 材の役割を持つことが報告されている(5).

自動車の前席シートの構造は，主に金属製フレームと多孔 質材のフォームと表皮材から構成されている。一方，後席シ 一トの構造では，金属製パネルにフォームと表皮材が積層さ れている，実際にはその他に電動装置などが装備されており 複雑な構成となっている.

シートに用いられるフォームは, ミクロで考えると, 連続し た細孔内の空気と樹脂の骨格からなっている，それぞれが音 波や振動を伝達できる媒質となりうる，さらに両者を伝達す る波動が連成することが考えられる。このような特性を有す る自動車用シートのフォームと金属製フレームや金属製パネ ルとの振動音響連成を検討した報告はない。

本報告では，拚散場とはみなせない低中周波数領域に着目 し, 前席および後席の自動車用シート構造を簡易モデル化し てハンマリング加振実験と音響加振実験を行い，シート構造 の振動音響連成特性を調べた.
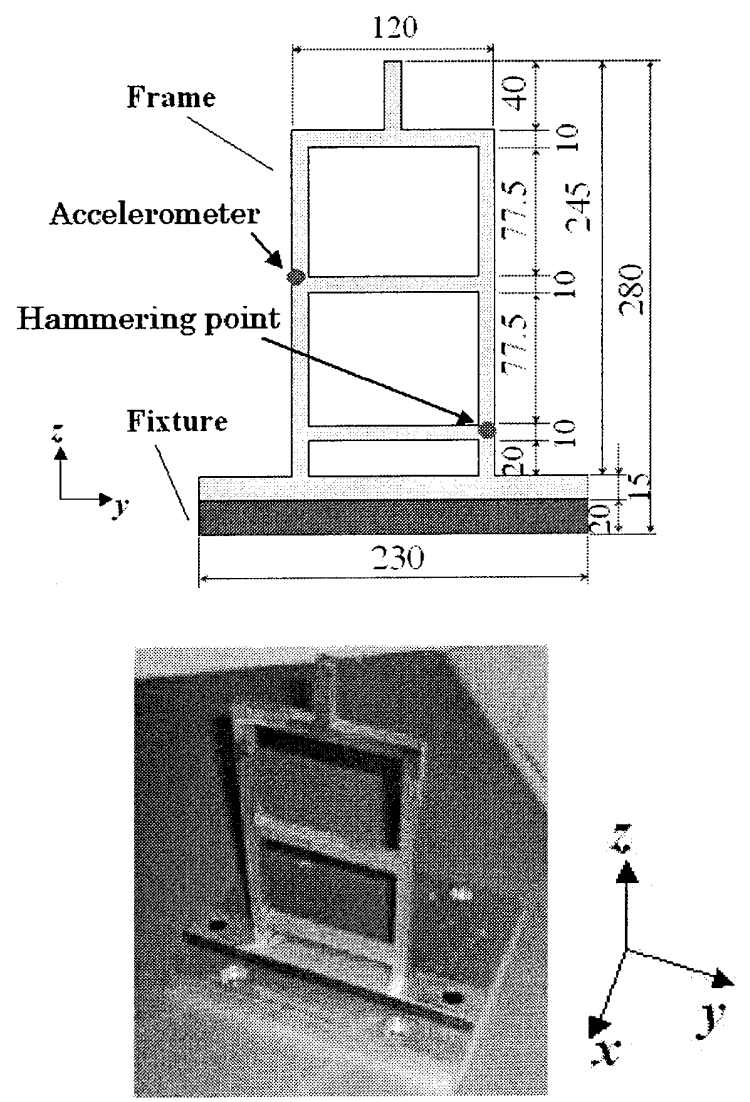

Fig.1 Specimen of a frame for a front seat structure

\section{2. 前席シート構造の加振実験 \\ 2. 1 前席シート構造の簡易モデル}

図 1 亿前席シート構造の簡易モデルの外観を示す. 図 1 に 示すような「月」の字状のフレームの下部を，治具を介して 固定した．図 1 に示寸寸法のフレームを用いた．フレームの 断面は $10 \mathrm{~mm} \times 10 \mathrm{~mm}$ の正方形である.フレームはアルミニウム 製であり，接合部がなく一体構造としてある.フレームは， 高さ $20 \mathrm{~mm}$ 幅 $230 \mathrm{~mm}$ 奥行き $180 \mathrm{~mm}$ の治具にボルトで接合した。

このフレームに, 自動車シート用のウレタンフォームのブ ロックを，両面テープで接着した．フォームの寸法は，高さ $213 \mathrm{~mm}$ 幅 $150 \mathrm{~mm}$ 厚さ $50 \mathrm{~mm}$ で，フレームに図 2 のような位置に 両面テープを用いて接着した. ここで用いたウレタンフォー ムのブロックは，大きなブロックをスライスして作成してお り，表面には皮膜などが無い条件にしてある.

さらに，フレームに取り付けたウレタンフォームに底面と フレームとの接着部分を除いた全面にシートの表皮材として 厚さ $1.5 \mathrm{~mm}$ の本革を両面テープで接着した。

このフレーム, フォーム, 本革からなる前席シート構造の 簡易モデルを, 定盤に固定してハンマリング加振実験を行っ た．さらに簡易モデルを，車内空間を模擬した閉空間中に設 置し，音響加振実験を行った。
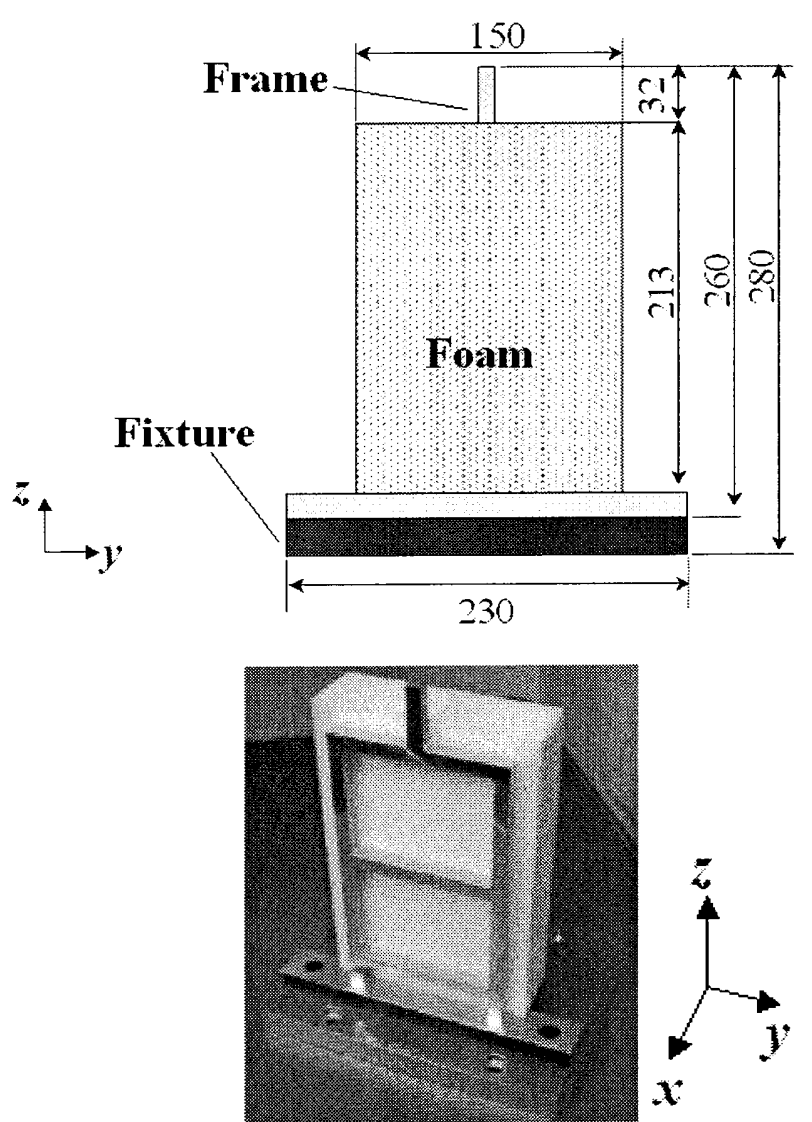

Fig.2 Specimen of a frame with foam for a front seat structure 


\section{2. 前席シート構造のハンマリング加振実験}

圧電体力変換子を内蔵したインパクトハンマーによる衝撃 加振実験を行い．まず，フレームの構造振動におよぼすフォ 一ムの影響を調べた．図 1 に示すフレームの一点を加振し， 力変換子から入力 $F$ を計測した. フレームの他点に加速度ピ ックアップを設置し，加速度 $A$ を計測した．FFTにより周波 数応答（イナータンス伝達関数 $A / F$ ) を求めた. フレームは 治具を介して定盤に固定してあり，加振方向と観測方向は， いずれも図中の $x$ 方向である. ハンマリングで得られたイナ 一タンス伝達関数 (加速度 $A /$ 力 $F$ ) のゲインを図 3 に示す. 図 3には三個の大きなピークが現れている.フレームのみの条 件で現れた $112 \mathrm{~Hz}$ のピークは, フレームを片持ちはりとする $x$ 方向の 1 次曲げ変形モードであり, $379 \mathrm{~Hz}$ のピークは $z$ 軸ま わりのフレームの 1 次ねじり変形モード， $638 \mathrm{~Hz}$ のピークは フレームを片持ちはりとする $x$ 方向の 2 次曲げ変形モードで ある.フレームのみの場合とフォームを接着した場合のゲイ ンのピークを比べると，フォームがある場合のピークの振幅 が減少している．さらに，本革を接着するとゲインのピーク が全体的に小さくなっている。

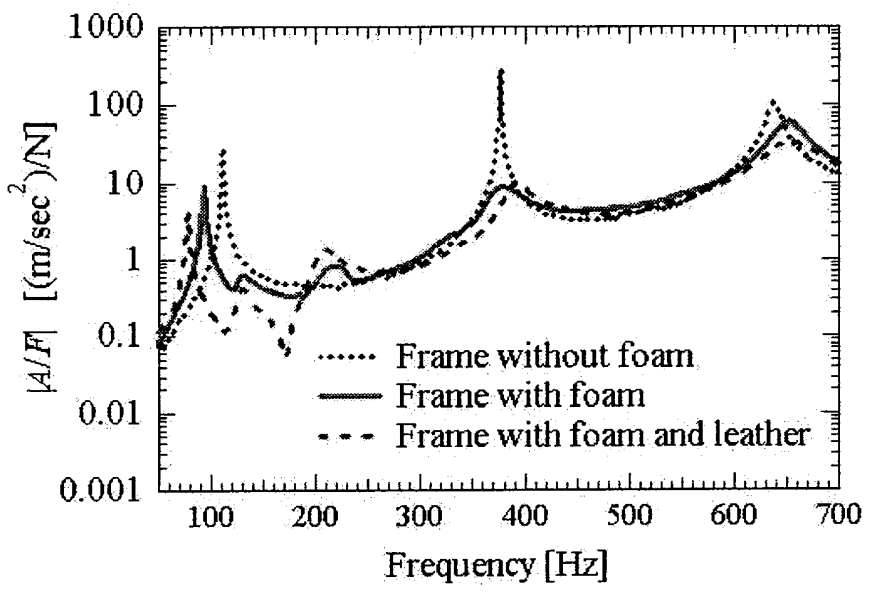

Fig. 3 Inertance of a front seat structure from the hammering test

イナータンス(加速度/カ)のゲインをズーミングし,半值幅 法で各共振ピークにおける減衰值(モード減衰比)を求めた。 図 4 に測定結果を示寸，横軸は共振周波数[Hz]であり縦軸は モード減衰比[-]である．図4 からフォームがある場合のほう が，フレームのみの場合に比べ，モード滅衰比がいずれの共 振においても増加しており，制振効果が確認できる.また， 本革をフォーム表面に接着した場合も，フレームのみの場合 に比べてモード減衰比が増大している， $x$ 方向の 1 次と 2 次 の曲げ変形モードにおいては，本革の接着によりモード減衰 比が大きくなっている.

\section{3. 前席シ一ト構造の音響加振実験}

図 5 は音響加振実験の実験装置の概要である.図 5 の左側の小さなボックスにはスピーカーが内蔵され

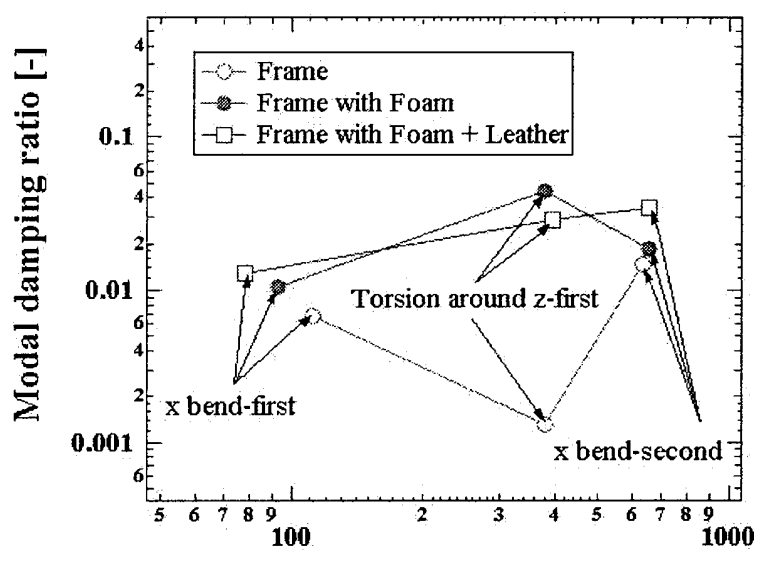

Fig. 4 Resonant frequencies and modal loss factors of a front seat structure

ている.図の右側の大きなボックスは, 車室を模擬し た閉空間の内部である。この閉空閒用のボックスの 中央付近に前席シート構造を設置した。スピーカー ボックスと閉空間用のボックスをパイプで連結し， 閉空間をホワイトノイズで音響加振した。床からの 振動伝達を避けるためにボックスの下には防振ゴム マットを敷いた。図 1 で示したシートモデルの底面 を, 図 5 の位置に閉空間用ボックスにボルトで固定 L Ch. 1 (連結パイプ部音圧 $P_{1}$ ), Ch. 2 (閉空間内部音圧 $\left.P_{2}\right)$ の位置にそれぞれマイクロフォンを設置した。図 5 の左端のボックスよりスピーカーを用いて音圧加 振し,Ch. 1, Ch. 2 間の伝達関数 $P_{2} / P_{1}$ を求めた。これよ りシートによる音場の吸音特性を調べた。さらに八

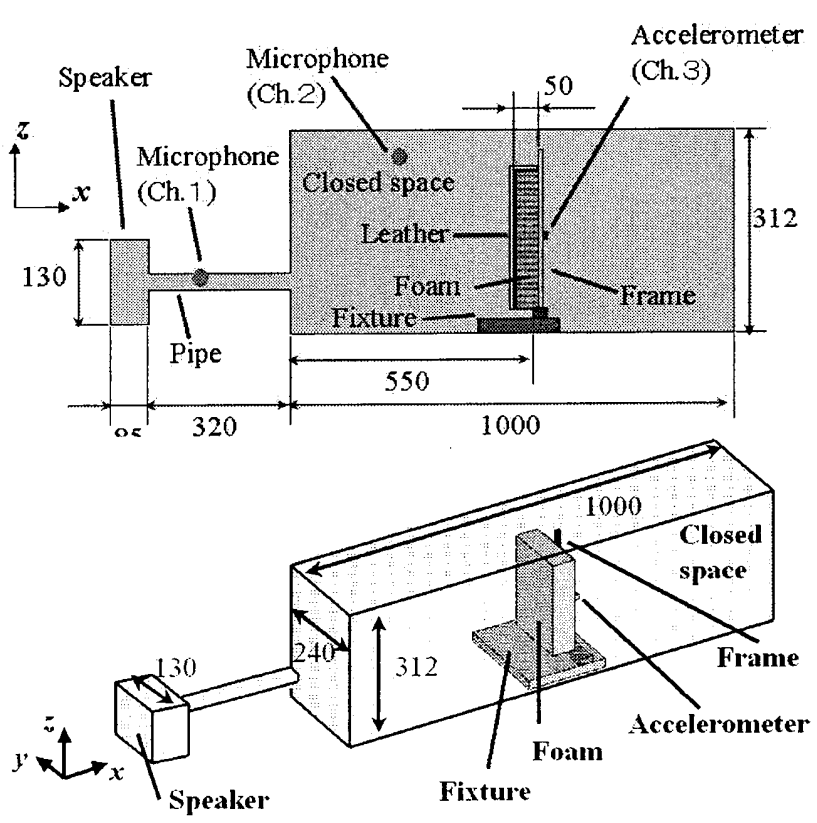

Fig.5 Experiment setup of acoustic excitation test for a front seat structure 
ンマリング加振実験の時と同様に前席シート構造の フレームに加速度計 Ch. 3(シート部の加速度 $A_{3}$ )を設 置し, Ch. 1(連結パイプ部音圧 $P_{1}$ ) との閒の伝達関数 $\left(A_{3} / P_{1}\right)$ を計測した。

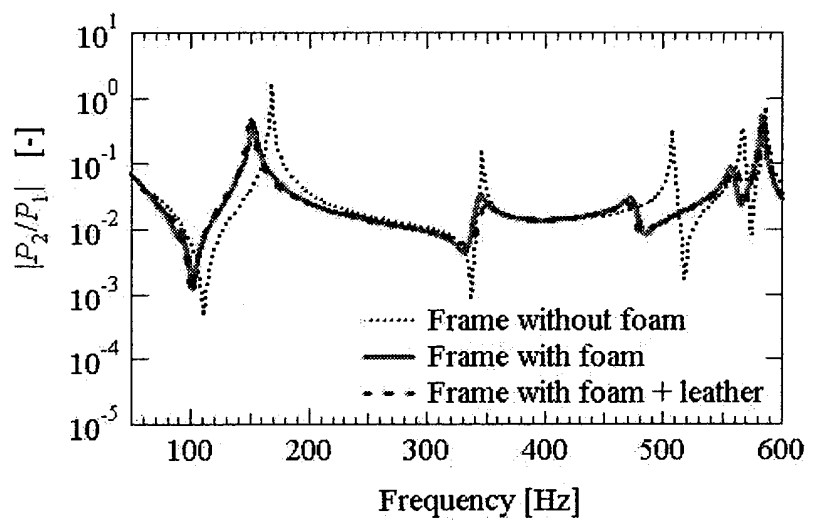

Fig.6 Sound pressure in the closed space with a front seat

structure

音響加振の場合, 伝達関数の基準はスピーカーが発生する 体積速度とす心゙きである。音圧を基準とすると，マイクロフ オンの位置が音響モードの節と一致した周波数の近傍で伝達 関数がピークとなるため, 振動の伝達関数のピークと周波数 が一致しないという問題が出る。しかし，今回実験を行った 周波数域では，スピーカーと閉空間ボックスを接続する連結 パイプ部が音響モードの節となることがないため，測定が容 易なパイプ部の音圧を伝達関数の基準とした.

図6は，スピーカーで音響加振を行い閉空間内の一点の音 圧 $P_{2}$ を測定し, 連結パイプ部の音圧 $P_{1}$ との伝達関数のゲイ ン $\left|P_{2} / P_{1}\right|$ を求めた結果である. 図 6 中の $169 \mathrm{~Hz}, 347 \mathrm{~Hz}, 508 \mathrm{~Hz}$ のピークは，それぞれボックスの内部閉空間の $x$ 方向 1 次, $x$ 方向 2 次, $x$ 方向 3 次共鳴である. いずれもフォームが有る 場合のピークの高さが，フォームがない場合に比べて下がっ ている. フレームのみの場合のピークは，鋭く尖っておりフ オームを有することにより，空間の共鳴を減衰させる吸音効 果が確認できる. 特に $x$ 方向 1 次共鳴は, $169 \mathrm{~Hz}$ と低周波数 であるが, モード減衰比はフレームのみ条件では 0.0037 であ ったのが，フォームがある条件で 0.016 人と約 4 倍に増加し ており，吸音効果が現れている.これは $x$ 万向 1 次共鳴にお ける粒子速度分布の腹の位置(閉空間の $x$ 方向の中央付近)に, 前席シート構造が設置されているためである．本革がある条 件ではモード減衰比は 0.011 となりフォームのみの条件より も值が小さくなり吸音効果が低下した．通気性がない本革に よりフォーム内部への音波透過が少なくなったためである.

スピーカ一加振でフレームの加速度 $A_{3}$ を求め, 連結パイ プ部音圧 $P_{1}$ との伝達関数のゲイン $\left|A_{3} / P_{1}\right|$ を計測した 結果を図 7 に示す.フォームがない条件での $112 \mathrm{~Hz}$ のピーク は，フレームを片持ちはりとする $x$ 方向の 1 次曲げ変形モ一

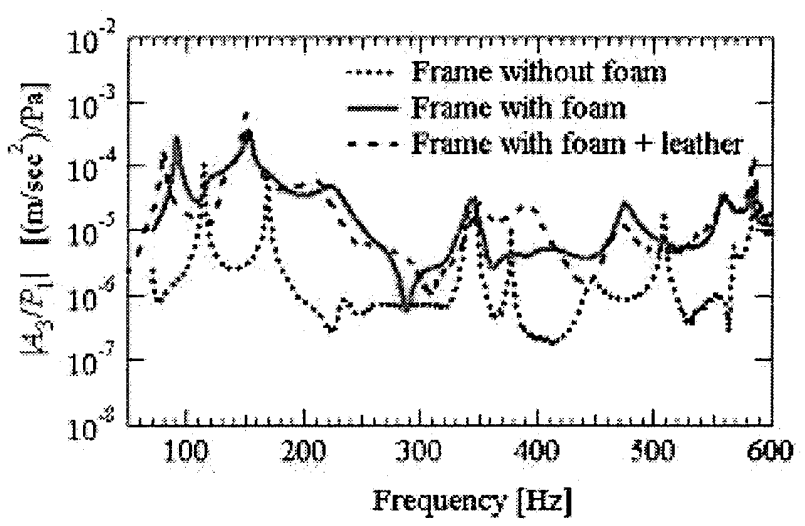

Fig.7 Acceleration of a front seat structure under acoustic excitation

ドであり，図3のハンマリングでも現れた共振である. フォ 一ムをフレームに接着すると,このピークの振幅は, 図 3 の八 ンマリングとは異なり, なんと上昇した. しかし,このピーク はフォーム接着により先鋭度が下がっている，モード減衰 比は，フォームが無い条件では 0.0036 であったのが, フォ 一ムがある条件では 0.013 へと増加しており，減衰そのもの は増えているが加速度は増大している。 この時, フォーム接 着により共振周波数は $91.3 \mathrm{~Hz}$ に低下しているが, これはハン マリングでの結果どおりである，本革がある場合も，フレー ムのみの条件からモード減衰比は 0.0036 から 0.014 と増大し たが，加速度は増大した。

図 7 でフォームが無い場合の $169 \mathrm{~Hz}$ 近傍のピークは, 図 6 でも現れた閉空間の $x$ 方向 1 次共鳴である.このピークも, フォームをフレームに接着した場合のほうが, フレームのみ の場合に比べて，なんと振幅が増大した。 しかし，フォーム がある場合のピークの形状は丸くなった。この時もモード減 衰比は, フォームが無い条件の 0,0037 からフォームのみ取り 付けた場合の 0.016 人と增大した. すなわち，この場合も減 衰は増加しているが, 加速度が増大した. また, 本革がある 条件でも，フレームのみの条件に比べ，モード減衰比は 0.0037 から 0.011 へと増大寸るが，加速度は増大してしまっ ている.

同様に，フォームの有無で図 7 の応答全体を比較すると， フォームが有る方の応答レベルが, 全体的に大きい.これは, フォームが「帆の役割」を果たし, フレームの振動を増大さ せてしまうと考えられる. フレームのみの場合に比ベフォー ムがある場合の方が音圧を受ける表面積が，増大することに 起因すると考えられる. 本革がある場合も同様な現象が起こ っていると考えられる.

なお，図 7 でフォームが無い場合の $169 \mathrm{~Hz}$ 近傍のピークに 対応する閉空間 $x$ 方向 1 次共鳴について，本革がある場合の モード滅衰比は,フォームのみの場合よりも 0.016 から 0.011 へと低下しているが，これは，本革に通気性がないため，フ オーム内部への音波の侵入が減り吸音効果が減少した. 


\section{3. 後席シ一ト構造の加振実験}

\section{1. 後席シート構造の簡易モデル}

後席シート構造を模擬するために，図8のように高さ $220 \mathrm{~mm}$, 幅 $150 \mathrm{~mm}$, 厚さ $0.8 \mathrm{~mm}$ の鋼板に, 前席シート構造で用い たウレタンフォームのブロックを両面テープで，板全面を拧 おうように接着した．さらに，ウレタンフォームの前面に厚 $1.5 \mathrm{~mm}$ の本革を両面テープで接着した。この鋼板の全周縁を 治具にボルトで固定した。

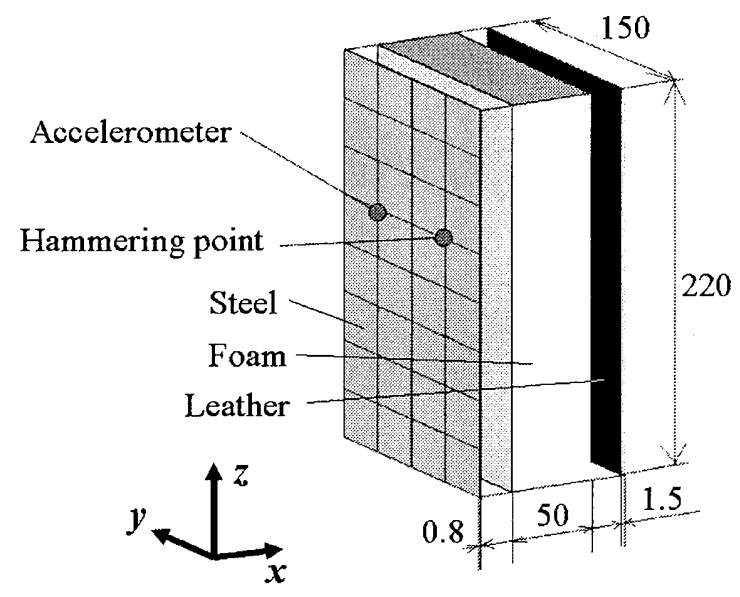

Fig.8 Specimen of a steel frame with foam for a rear seat structure

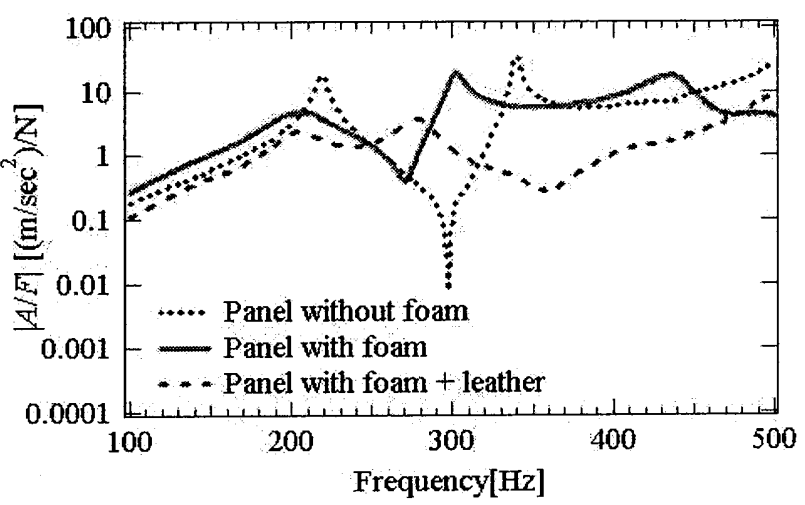

Fig.9 Inertance of a rear seat structure from the hammering test

\section{2. 後席シート構造のハンマリング加振実験結果}

ハンマリング加振実験で得られたイナータンス伝達関数 (加速度 $A /$ 力 $F$ ) のゲインを図 9 に示す．観測点と加振点を 図 8 に示す. 図 9 のパネルのみの条件での低い周波数から 1 , 2 番目のピークはそれぞれ鋼製パネルの $(1,1) ，(1,2)$ の 曲 げ共振モードである.ただし, $(a, b)$ は,それぞれ板の短辺方向 (y 方向) と長辺方向 $(\mathrm{z}$ 方向) の半波長の波数である. パネルの みの場合とパネルにフォームを接着した場合のゲインのピー クを比較すると，フォームがある場合のピークの振幅が减少 し制振されていることが確認できる.

\section{3. 後席シ一ト構造の音敕加振実験結果}

図 8 の後席シ一ト構造の簡易モデルを，図 5 と同様に閉空
間内の中央付近に図 10 のように設置した。これにより閉空 間は二つの部屋に分割される。これで実車の車室とトランク ルームの間に後席シート構造が設置される状況を反映させた。 スピーカーで音響加振し, 前席と同様に Ch1 として連 結パイプ部の音圧 $P_{1}, \mathrm{Ch} .2$ として閉空間内部音压 $P_{2}$ を 測定し，両者の音圧の伝達関数 $P_{2} / P_{1}$ のゲインを求め た。結果を図11に示す。フォームがない条件の $212 \mathrm{~Hz}$ の小さなピークは, パネルの $(1,1)$ 曲げ共振で あり，ハンマリングの図 9 に現れていた共振である。 図 11 で $324 \mathrm{~Hz}$ の大きなピークはCh. 3 のマイクが設 置してある側の閉空間内の $x$ 方向の一次共鳴である. このピークはフォームがある場合にほぼ消失してお り, シートのフォームによる吸音効果が確認できる。 本革を取り付けた条件ではフォームのみの条件比べ るとグラフに大きな変化は見られない。
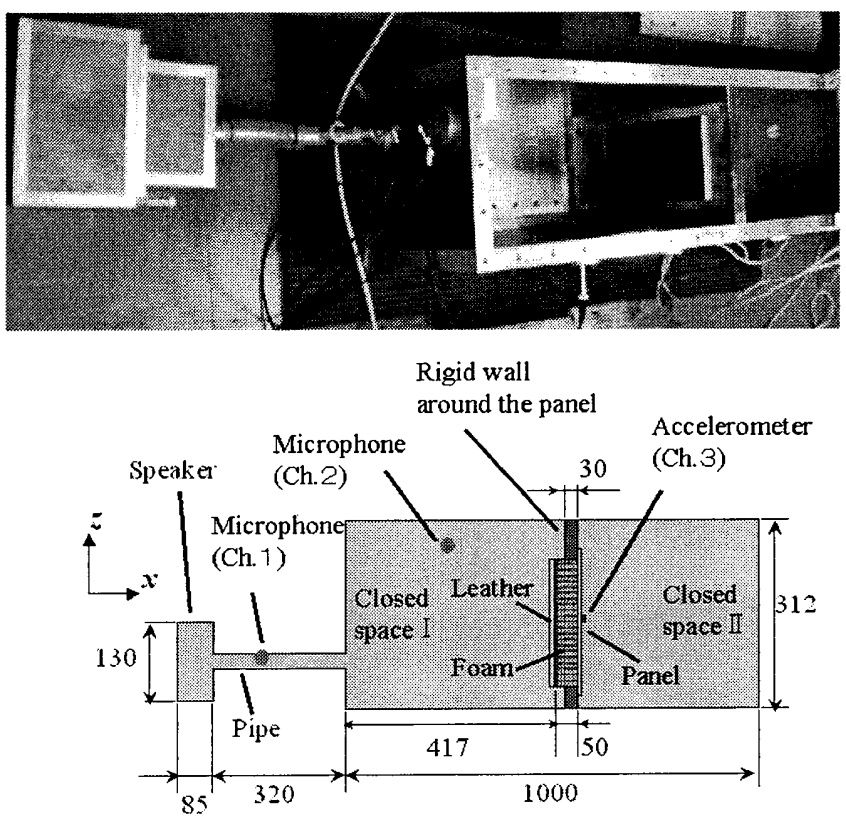

Fig.10 Experiment setup of a rear seat structure for acoustic excitation

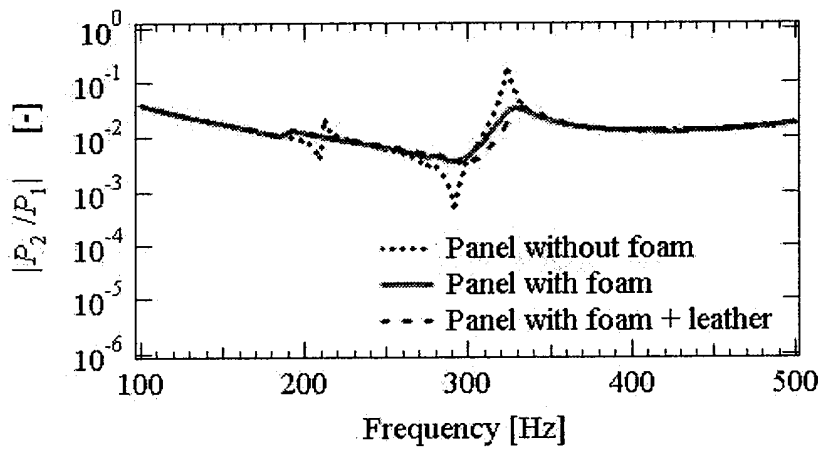

Fig.11. Sound pressure in the closed space having a panel with a foam (rear seat structure) 
後席シート構造の鋼板に加速度計 Ch. 3(シート部の 加速度 $A_{3}$ ) 設置し, Ch1 のパイプ部の音圧との間の 伝達関数 $\left(A_{3} / P_{1}\right)$ を計測した. 結果を図 12 に示す. 加 速度の観測点は図 8 と同じ位置である。フォームが 無い場合の $223 \mathrm{~Hz}$ のピークはパネルの $(1,1)$ 曲げ共振 であり，ハンマリングの図 9 にも現れていた共振で ある、フォームがあると,このピークの振幅は小さく なりピークも丸くなっているので, ハンマリングと 同様に制振されている.フォームが無い場合の $323 \mathrm{~Hz}$ のピークは,図 11 にも現れた閉空間の共鳴でパネ ルが加振されて出現したピークである.このピーク は，フォームがあると図 11 と同様に吸音で消失す るので，パネルの加速度も小さくなっている。本革

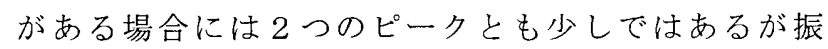
幅が減少している。

図 12 の結果をフォームの有無で全体的に比較すると, 前席モデルで現れたようなフォーム接着による鋼製パネルの 振動振幅の増大は現れず，逆に制振されている．後席シート 構造ではパネルのみの場合とパネルにフォームを接着した場 合で，音圧を受ける表面積が，前席と異なり大きく変わらな い. したがって，制振効果や吸音効果の影響が，そのまま音 響加振におけるパネルの加速度に現れたと考えられる. 本革 がある条件でも同様な現象が現れた。

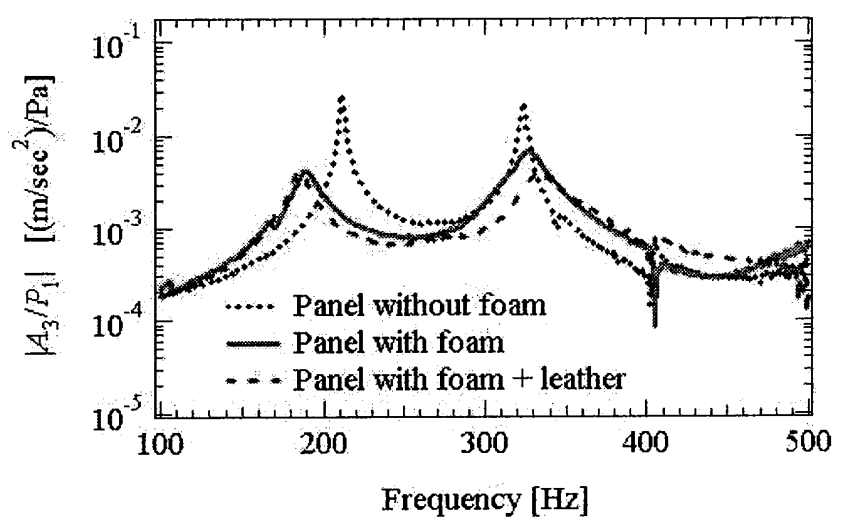

Fig.12 Acceleration of a panel with a foam under acoustic excitation (rear seat structure)

\section{4. 結 言}

自動車用のシート構造の振動音響特性を，簡易モデルを用 いて，実験解析を行った．前席を模擬した金属製フレームと 後席を模擬した金属製パネルにシートのフォーム，本革を接 着し，振動音響連成特性を評価した，ハンマリングによる加 振実験から，シートのフォームには金属フレームあるいは金 属製パネルの振動を制振する効果が確認できた．また，シー トの本革にも振動の制振効果が確認できたが, フォームほど の効果はない，音響加振実験から，シートのフォームが存在 すると閉空間内部の音の共鳴は吸音されることが確認できた.
本革による吸音効果は余り確認できなかった．さらに音響加 振実験から，シートのフォームがあることにより金属製フレ 一ムの振動を増大させるという，『帆のはたらき』が観測さ れた. フレームのみの場合に比べフォームがある場合の方が 音圧を受ける表面積が，増大することに起因する．本革があ る条件でも同様な現象が現れた。

一方，同様な音響加振実験を，フォームを接着した金属製 パネルで実施すると，金属製パネルの振動は増大せずに，制 振された. 後席シート構造ではパネルのみの場合とパネルに フォームを接着した場合で, 音圧を受ける表面積が, 前席と 異なり大きく変わらないことに起因する.

\section{5.あとがき}

本報告の作成で群馬大学院工学研究科機械システム工学専 攻 金井智幸君, 群馬大学工学部機械システム工学科 上田 啓介君にご協力を頂きました．謝意を表します。

\section{参 考 文 献}

(1) T. Yamamoto, S. Maruyama and T. Yamaguchi : Characterization of Passenger Seats for Noise and Vibration Using Poroelastic Element (Second Report), Proceedings of Society of Automotive Engineering of Japan Annual Congress (Spring), 2010.

(2) M. A. Sanderson and T. Onsay, CAE interior cavity model validation using acoustic modal analysis, $S A E$ paper, 2007-01-2167.

(3) H. Tada, Y. Kamiyama, F. Ide, K. Misaji, K. Hirosawa, H. Nakagawa, M. Kon and A. Yamamoto : FE modeling scheme using experimentally measured acoustic impedance for sound proof package, SAE paper, 2009-01-0608.

(4) D. J. Nefske and S. H. Sung: An equivalent-acoustic finite element method for modeling sound absorbing materials, Journal of Acoustical Society of America, Vol. 123, P. 3570, 2008.

(5) P. Chen and G. Ebbitt : Noise Absorption of Automotive Seats. SAE paper, 980659, P. 117, 1998. 